Creative Commons User License: CC BY-NC-ND

Abstracted by: EBSCOhost, Electronic Journals Service (EJS),

Google Scholar, Journal Seek, Scientific Commons,

Food and Agricultural Organization (FAO), CABI and Scopus

http://eoi.citefactor.org/10.11226/v25i2
Journal of Agricultural Extension

Vol. 25 (2) April, 2021

ISSN(e): 24086851; ISSN(Print); 1119944X

http://journal.aesonnigeria.org

http://www.ajol.info/index.php/jae

Email: editorinchief@aesonnigeria.org

\title{
Evaluation of the Demand-Driven Agricultural Extension Curricula among Alumni from Selected Universities in Nigeria
}

https://dx.doi.org/10.4314/jae.v25i2.1

\section{Oladele Oladimeji Idowu}

Sasakawa African Fund for Extension Education. Nigeria/ Ethiopia

C/o Libreville street Wuse II Abuja.

Oladele20002001@yahoo.com

\section{Abstract}

The study assessed demand-driven agricultural extension curricula by alumni from universities in Nigeria partnering with Sasakawa Africa Fund for Extension Education (SAFE) on such curriculum for at least seven years. Using a cross-sectional research design and cluster sampling technique, 227 alumni were randomly selected from a population of 520. Data were collected through structured questionnaire on socio-economic characteristics, mode of study, areas of specialization operationalized as close-ended questions and rating of programme components on a 5 -point Likert type scale of poor (1) fair (2) good (3) very good (4) excellent (5) with 70 items. Data entry and analysis were done with SPSS 25 using percentages, mean score and multiple regression analysis. Adult education approaches, supervised enterprise projects, students' supervision, academic advice, information sharing, and participation in research projects had highest positive rating; while fund raising, scholarship, opportunity for enrolling and be part of a professional scientific network, linkage \& involvement with Sasakawa Africa Association (SAA) field activities, laboratories and variety of subjects offered had highest negative rating. Socio-economic characteristics of alumni were significantly correlated and explained 49 percent of the variation in programme rating. The study recommends that there is need to review the curricula covered in this study and mechanisms for compliance with the Sasakawa methodology should be reinvigorated.

Keywords: alumni, demand-driven, agricultural extension, university curricula.

\section{Introduction}

Curriculum assessment process has been a major tool for universities to produce graduate who are 'fit to practice' and to comply with professional, public, accrediting bodies' standards. Curriculum assessment as a process gathers and analyzes information from several sources to sustainably improve student learning. Curriculum assessment help to identify aspects of a curriculum that are functional and those requiring change, determining the effectiveness of changes made, indicating the effectiveness of the current programme, reviewing programme requirements and satisfying professional accreditations. Curriculum assessment often requires information on curriculum design, curriculum/course delivery, assessment, learning 
Creative Commons User License: CC BY-NC-ND

Abstracted by: EBSCOhost, Electronic Journals Service (EJS), Google Scholar, Journal Seek, Scientific Commons,

Food and Agricultural Organization (FAO), CABI and Scopus

http://eoi.citefactor.org/10.11226/v25i2
Journal of Agricultural Extension

Vol. 25 (2) April, 2021

ISSN(e): 24086851; ISSN(Print); 1119944X

http://journal.aesonnigeria.org

http://www.ajol.info/index.php/iae

Email: editorinchief@aesonnigeria.org

environment and the sources of information include all stakeholders relevant to the curriculum under assessment. The evaluation is usually done in every five years with some procedures within the years as proposed by Kumm and Laverentz (2017).

Quality control focusing on learning outcomes has become increasingly important in the field of accreditation of institutions of higher education (National University Commission) (NUC 2018); and when assessing learning outcomes, the accreditation bodies include several stakeholders: students, employers of graduates and alumni. Alumni-based evaluations are increasingly recognized as an important part of the process of curriculum evaluation. They provide insights into the undergraduate learning experience and students' preparation for work together with the views of other stakeholders including staff, students, employers and clients, alumni evaluations can provide useful feedback to curriculum designers (Cobb, Brown, Hammond, Mossop, 2015). Within higher education, there has been increasing emphasis placed on the intended learning outcomes (ILOs) of a course and this has led to the development of outcomes based curricula and later the concept of outcomes-based education (OBE) is based on the principle that the outcomes that students are expected to display at the end of the course are decided, and the curriculum is subsequently developed to enable it to achieve these outcomes which recently described as demand-driven curriculum (Suvin, 2018). Blumenstyk, (2019) emphasized that demand-driven education has been variously depicted as competency-based education and career-ready education such that "competencybased education (CBE) programmes, enhance learner's advancement by demonstrating mastery of specific competencies through practical assessments, rather than by completing a traditional, time-bound course while on the other hand, the term career-ready is generally applied to students who are considered to be equipped with the knowledge and skills deemed to be essential for success in the modern workforce, or the kinds of educational programmes and learning opportunities that lead to improved workforce preparation".

Oladele, (2020) states that the pluralism of agricultural extension delivery, advent of ICT and globalization processes particularly trade as well as changing consumers' needs and preferences in terms of quality, standards, safety, health along the value chain have led to farmers demanding more in areas required by market forces. The demand on farmers has led to demand from extension service providers to extension education in terms of improved training and capacity by Universities and Colleges. Career-ready education has to go beyond skill gaps, as hiring has become skillsbased, alternative credentials gain traction, and more jobs go digital (Blumenstyk, 2019).

Demand-driven education takes account of the emerging global economy technology-infused, gig-oriented, industry-driven - while also striving to ensure that new graduates and lifelong learners alike have the skills required to flourish," Demand-driven extension education develops and measures the specific skills that are mostly demanded; utilizes dynamic and work-based pedagogy to improve competencies, responds to the needs of the labour markets to ensure continuous 
Creative Commons User License: CC BY-NC-ND

Abstracted by: EBSCOhost, Electronic Journals Service (EJS), Google Scholar, Journal Seek, Scientific Commons,

Food and Agricultural Organization (FAO), CABI and Scopus

http://eoi.citefactor.org/10.11226/v25i2
Journal of Agricultural Extension

Vol. 25 (2) April, 2021

ISSN(e): 24086851; ISSN(Print); 1119944X

http://journal.aesonnigeria.org

http://www.ajol.info/index.php/jae

Email: editorinchief@aesonnigeria.org

alignment; creates pathways to allow learners to rapidly convert learning to earning; supports changes that make the entire education landscape function better, and creates the future of education alongside industry (World Bank 2015).

López-Entrambasaguas, Calero-García, Díaz-Meco-Niño, and Martínez-Linares, (2019) argued that to prevent drift and maintain quality, continuous review on curriculum is obligatory. For curricula to be relevant to the needs of society, faculty must be committed to continuous quality improvement, which involves curriculum evaluation, curriculum revision, and re-evaluation after implementation of changes (Billings \& Halsted, 2016; Valiga, 2017). Evaluation of curriculum can cover the whole or segments of the curriculum. "It includes course sequence, logical flow of experiences, alignment of concepts, the contribution of each course to the programme outcomes, use of evidence-based teaching methods, and student engagement" (Valiga, 2017). Formative and summative evaluation are often applied in curriculum review and evaluation such that as formative evaluation assesses the programme's development and implementation to find where changes are required to ensure quality; the summative evaluation determines if pre-defined outcomes of a programme outcomes were met (Kumm and Laverentz, 2017). This study applied the summative evaluation to determine competence among alumni.

Common areas that have been cited as areas of involvement of alumni with their alma maters include support (financial and others), academic ranking, role models, and curriculum evaluation and development. Cobb, Brown, Hammond, Mossop, (2015) reported that alumni involvement in curriculum is premised on the unique position to evaluate the effectiveness of their study in their professional lives in terms of what has been learnt and required for careers. In this way Alumni are often used as validators of achievements of past curricula, advisors on the current curriculum and designers of the shape of future curricula in the curriculum development and assessment processes.

Sasakawa Africa Association (SAA) [2018] is an international agricultural development non-governmental organization, established in 1986 and has been working on agricultural programmes in sub-Saharan countries but currently focusing on four countries (Ethiopia, Nigeria, Mali and Uganda); although the University component of SAA, the Sasakawa Africa Fund for Extension Education covers Malawi, Benin, Tanzania, Burkina Faso, Mozambique, Sierra Leone and Ghana in the area of human capital development. SAA works with national partners in agricultural landscape to improve the productivity and profitability of value chain actors by building their capacities along the entire agricultural value chain.

SAA (2018) stated that SAA thematic areas are Crop Productivity Enhancement (CPE), Postharvest Handling \& Agro-Processing (PHAP) and Human Resource Development often depicted as Sasakawa Africa Fund for Extension Education (SAFE) which was established in 1991 to contribute to building the institutional capacity of African universities and agricultural colleges to offer demand-driven training in agricultural extension. SAFE, partner universities and agricultural colleges 
Creative Commons User License: CC BY-NC-ND

Abstracted by: EBSCOhost, Electronic Journals Service (EJS), Google Scholar, Journal Seek, Scientific Commons,

Food and Agricultural Organization (FAO), CABI and Scopus
Journal of Agricultural Extension

Vol. 25 (2) April, 2021

ISSN(e): 24086851; ISSN(Print); 1119944X

http://journal.aesonnigeria.org

http://www.ajol.info/index.php/jae

Email: editorinchief@aesonnigeria.org

provide in-country, demand-driven training programmes. Mid-career extension agents are equipped with the necessary knowledge, skills and competencies to effectively and efficiently disseminate crucial agricultural information and technology to value chain actors, after mainstreaming value chain into curriculum of 26 universities in 11 countries of Africa (SAA 2018).

The pillars of SAFE's demand-driven training are: lifelong learning, demand-driven curricula, student-centered experiential learning and rural leadership development. The lifelong learning is implemented through alumni associations and network activities, demand-driven curriculum delivered through face to face, semi-distance and open-distance learning modes; while the experiential learning and rural leadership are anchored on Supervised Enterprise Projects (SEPs) and Enterprise centers (SAA, 2020). SEPs is an in-situ tool for capacity development and technology transfer, which enables the candidate to develop knowledge and skills on specific technology in question and simultaneously transfer technology to the community. It is underpinned by action research principles and theory but the sequence of activities in SEPs is uniquely different from other action research approaches in agriculture. SEPs has learning and development dimensions that includes multi-stakeholders platform, extension technology transfer, community development, enterprise development and learning and sharing. Faculty supervision support to students is critical to fostering lasting learning relationships in university outreach and thus, the needs to be a part of higher education sector for improved community linkages and innovation (Kalule et al, 2019). The enterprise center is a space where innovation development and dissemination processes are explored by students, farmers, lecturers and researchers for training and practice purposes with emphasis on commodity value chain activities and skill acquisition. In Nigeria, Table 1 shows the list of SAFE partner Universities.

Table 1: List of demand-driven agricultural extension curriculum in Nigeria as at 2020

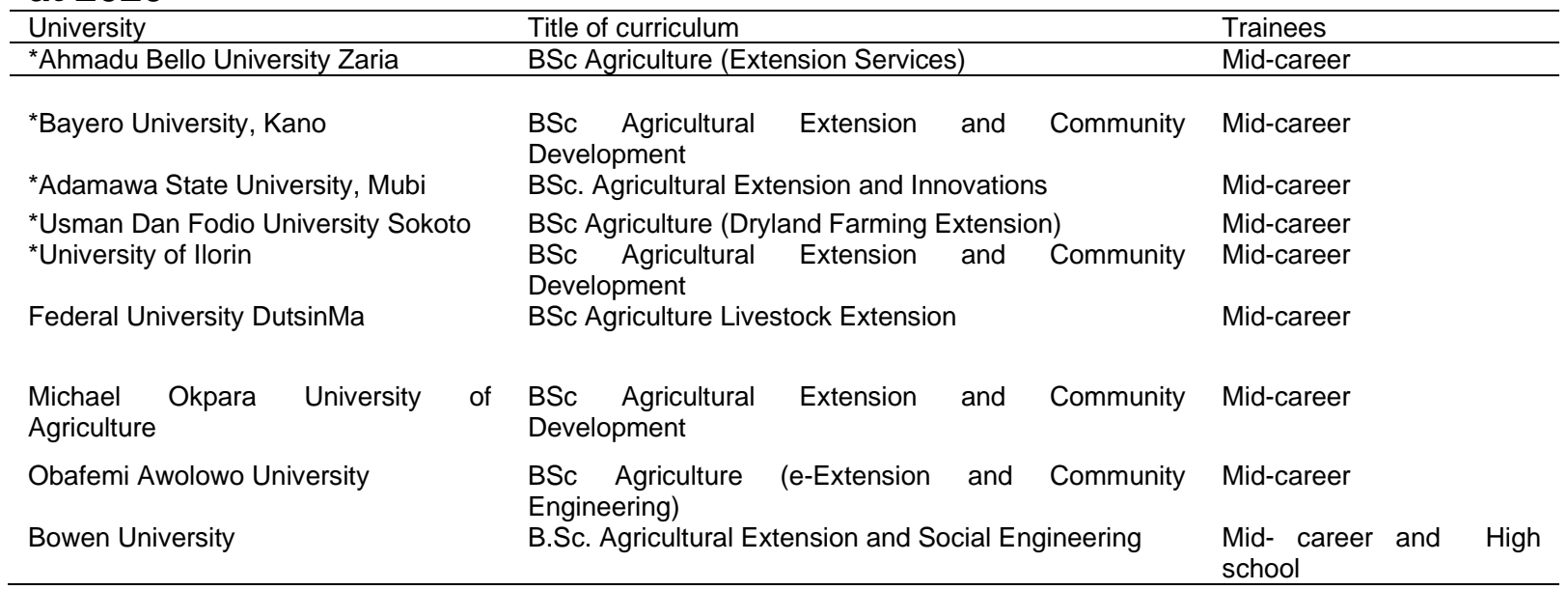


Creative Commons User License: CC BY-NC-ND

Abstracted by: EBSCOhost, Electronic Journals Service (EJS),

Google Scholar, Journal Seek, Scientific Commons,

Food and Agricultural Organization (FAO), CABI and Scopus
Journal of Agricultural Extension

Vol. 25 (2) April, 2021

ISSN(e): 24086851; ISSN(Print); 1119944X

http://journal.aesonnigeria.org

http://www.ajol.info/index.php/jae

Email: editorinchief@aesonnigeria.org

The following steps according to Oladele (2020) are implemented to introduce demand-driven curriculum to universities: expression of interest by universities, need assessment, stakeholders' prioritization and validation of need assessment, MOU with stakeholders and relevant partners, curriculum development and approval, modules development, workshops for lecturers, partners and students on supervised enterprise projects (SEPs), advertisement and enrollment of mid-career students, establishment of Enterprise Centers and regular technical backstopping and visit.

The theory underlining this assessment is based on Donald Kirkpatrick's four levels of evaluation, which was postulated for training environments, to understand the 'how' and 'when' of curriculum assessment. According to Smith (2020), the levels are reaction - (a learning experience, meaning and importance), learning- (actual learning in knowledge, skills, and values), behaviour - (transformed behavior, behavioural changes over time) and results - (return on investment such as graduation rates, job placement rates, and success rates in competitive scholarship). According to Kirkpatrick, evaluation should always cover and begin with first level, and then, move sequentially through other levels. Information from each prior level serves as a base for evaluation at the next level. Though not all levels are always measured, each successive level represents a more precise measure of the effectiveness of the training programme, but at the same time requires a more rigorous and time-consuming analysis.

In Nigeria and other developing countries, one of the major challenges associated with extension services delivery is the low competence of extension officers. In response, Sasakawa Africa Fund for Extension Education had introduced a demanddriven, experiential curricula for capacity development of mid-career extension officers since 2001 in Nigeria due to the fact that conventional degree programmes do not have high experiential components. Over 500 extension officers had graduated since inception of the programme, however there has not been any assessment from Alumni's perspective on the programme.

\section{Objectives of the study}

The main objective of this study was to conduct alumni assessment of demanddriven agricultural extension curricula in Nigeria. The specific objectives were to identify the socio-economic characteristics, mode of study, areas of specialization of Alumni and assessment of programme components by the Alumni.

\section{Methodology}

The study was conducted in universities in Nigeria where the Sasakawa Africa Fund for Extension Education demand -driven curriculum had been introduced for more than seven years. These universities have variants of the demand-driven curriculum based on the consensus of stakeholders and provide training to mid-career extension officers in Nigeria- Ahmadu Bello University Zaria (BSc Agriculture (Extension Services), Bayero University, Kano (BSc Agricultural Extension and Community Development), Adamawa State University, Mubi (BSc. Agricultural Extension and Innovations), Usman Dan Fodio University Sokoto (BSc Agriculture 
Creative Commons User License: CC BY-NC-ND

Abstracted by: EBSCOhost, Electronic Journals Service (EJS),

Google Scholar, Journal Seek, Scientific Commons,

Food and Agricultural Organization (FAO), CABI and Scopus

http://eoi.citefactor.org/10.11226/v25i2
Journal of Agricultural Extension

Vol. 25 (2) April, 2021

ISSN(e): 24086851; ISSN(Print); 1119944X

http://journal.aesonnigeria.org

http://www.ajol.info/index.php/jae

Email: editorinchief@aesonnigeria.org

(Dryland Farming Extension) and University of Ilorin(BSc Agricultural Extension and Community Development). These are the only partner universities where Sasakawa Africa Fund for Extension Education are operational in Nigeria.

This study used cross-sectional research design. The population for this study included all alumni of SAFE demand -driven curriculum in Ahmadu Bello University Zaria, Bayero University, Kano, Adamawa State University, Mubi, Usman Dan Fodio University Sokoto and University of Ilorin. These are 520 according to SAA Annual report 2010.

The sampling procedure used in this study is cluster sampling. Alumni from each of the universities constitute the cluster for sampling, from which alumni were selected randomly to give 227 respondents. Frame error was controlled by excluding other alumni of the same universities under the conventional degree programme, while selection error was eliminated by ensuring that only those who completed the demand-driven programme were selected.

Data were collected through structured questionnaire which was made of sections on socio-economic characteristics, mode of study, areas of specialization and rating of programme components. A 5-point Likert-type scale poor (1) fair (2) good (3) very good (4) excellent (5) was used to measure components of the programme. The scale had 70 items covering study conditions, study provisions, teaching-learning environment, and study- programme as basis for future professional life. The questionnaire was subjected to face validity by Sasakawa coordinators across universities (5) and other lecturers (20) in the faculties where the demand-driven curriculum is being implemented. A split-half technique was used to ascertain the reliability of the rating scale used by alumni to evaluate the curricula with a reliability coefficient of $r=0.87$. The questionnaire elicited responses from Alumni on the questions developed from each of the specific objectives. The questionnaire was administered between May and July 2019. Data entry and analysis were done using SPSS 25 with the application of statistical tools such as frequency counts, percentages and linear regression and the implicit function for the Ordinary Least Square

(OLS) is as follows:

$Y t=\beta 1+\beta 1 X 1+\beta 2 X 2+\beta 3 X 3+\beta 4 X 4+$ $+\mathrm{e} 0$

Where: $\mathrm{Yt}=$ Programme rating, $\beta 1=$ Parameter estimate, $\mathrm{X} 1-\mathrm{X} 17$ independent variables, and $\mathrm{e}=$ Error term

The OLS function was applied on variables described in Table 2 
Creative Commons User License: CC BY-NC-ND

Abstracted by: EBSCOhost, Electronic Journals Service (EJS),

Google Scholar, Journal Seek, Scientific Commons,

Food and Agricultural Organization (FAO), CABI and Scopus

http://eoi.citefactor.org/10.11226/v25i2
Journal of Agricultural Extension

Vol. 25 (2) April, 2021

ISSN(e): 24086851; ISSN(Print); 1119944X

http://journal.aesonnigeria.org

http://www.ajol.info/index.php/jae

Email: editorinchief@aesonnigeria.org

Table 2: Description of variables

Variables Description

Programme rating $(\mathrm{Y}) \quad$ A composite score of 70 items covering study conditions, study provisions, teaching environment, study programme as basis for future professional life

Sex of graduate Dummy for gender of household head ( $1=$ male, $2=$ female)

Age of graduate in years Age of alumni in years

Marital Status Dummy for marital status

Level of father'sDummy for Level up to which father have studied

education

Level of mother'sDummy for Level up to which mother have studied

education

Father's occupation Dummy for father's occupation

Mother's occupation Dummy for mother's occupation

Brother's occupation Dummy for brother's occupation

Sister's occupation Dummy for sister's occupation

University of graduation Dummy for alumni university of graduation

Year of graduation Alumni year of graduation

Title of degree Dummy for alumni title of degree

Class of degree received First class-4, second class upper-3, second class lower -2 , third class- 1 , pass- 0

Area of specialization Dummy for special area trained

Year awarded degree Dummy for year of degree awarded

Mode of Study

Fulltime- 2, part time -1

Other

tertiaryDummy for possession of other tertiary qualification

qualification

\section{Results and Discussions}

\section{Characteristics of Alumni}

The socio-economic characteristics of alumni are presented in Table 3, shows that 79.7 percent are male, 45.4 percent are between 41-50 years of age, 89.4 percent are married, 24.2 percent graduated from Ahmadu Bello University (ABU), Zaria and 24.2 percent graduated in 2018. The trends of the results can be attributed to the fact that the majority of extension agents were male in Nigeria. Similarly, the fact that the programme started in ABU Nigeria in 2001 as the pioneer university for SAFE programme. Majority of extension agents were married and between 40 to 50 years. Olorunfemi, Olorunfemi, and Oladele (2020) stated that the mean age of extension agents in South West Nigeria was 40.2 years. Alabi, Ajayi, Fapojuwo, and Alabi, (2020) reported similar findings among extension agents in Nigeria. The results further show that 59.9 percent obtained Second Class Upper division, 48.90 percent specialized in agricultural extension and 99.9 percent had fulltime mode of study. 
Creative Commons User License: CC BY-NC-ND

Abstracted by: EBSCOhost, Electronic Journals Service (EJS), Google Scholar, Journal Seek, Scientific Commons,

Food and Agricultural Organization (FAO), CABI and Scopus

http://eoi.citefactor.org/10.11226/v25i2
Journal of Agricultural Extension

Vol. 25 (2) April, 2021

ISSN(e): 24086851; ISSN(Print); 1119944X

http://journal.aesonnigeria.org

http://www.ajol.info/index.php/jae

Email: editorinchief@aesonnigeria.org

Table 3: Distribution of alumni according to socio-economic characteristics

\begin{tabular}{ll}
\hline Variables & Percentages $(\mathrm{n}=227)$ \\
\hline Gender & \\
Male & 79.7 \\
Female & 20.3 \\
Age & \\
Less than 30 & 2.64 \\
$30-40$ & 30.00 \\
41 -50 & 45.37 \\
50 -60 & 20.70 \\
Above 60 & 1.32 \\
Marital status & \\
Married & 89.4 \\
Divorced & 3.5 \\
Single/Unmarried & 6.2 \\
Widow(er) & 0.9 \\
University attended & \\
ADSU & 20.7 \\
UNILORIN & 9.3 \\
UDUS & 22.5 \\
BUK & 23.4 \\
ABU & 24.2 \\
Year of Graduation & \\
2005 & 0.4 \\
2006 & 0.9 \\
2008 & 3.1 \\
2009 2010 & 1.8 \\
2011 & 8.4 \\
2012 & 1.8 \\
2013 & 3.1 \\
2014 & 0.4 \\
2015 & 4.4 \\
2016 & 3.1 \\
2017 & 10.1 \\
2018 & 18.5 \\
2019 & 24.2 \\
Class of degree & 19.8 \\
First Class & \\
Second Class Upper & 3.1 \\
Second Class Lower & 59.9 \\
Pass & 36.1 \\
Areas of specialization & 0.8 \\
Animal Production & \\
Crop Protection & 22.5 \\
Agronomy & 7.5 \\
Postharvest & 12.3 \\
Agricultural Extension & 5.7 \\
Agricultural Economics & 48.90 \\
Food Processing & 0.9 \\
Mode of study & 2.4 \\
Full time & \\
Part time & 0.4 \\
\hline &
\end{tabular}


Creative Commons User License: CC BY-NC-ND

Abstracted by: EBSCOhost, Electronic Journals Service (EJS),

Google Scholar, Journal Seek, Scientific Commons,

Food and Agricultural Organization (FAO), CABI and Scopus
Journal of Agricultural Extension

Vol. 25 (2) April, 2021

ISSN(e): 24086851; ISSN(Print); 1119944X

http://journal.aesonnigeria.org

http://www.ajol.info/index.php/jae

Email: editorinchief@aesonnigeria.org

A 5-point- Likert type scale Poor (1) Fair (2) Good (3) Very Good (4) Excellent (5) was used to measure alumni's rating of demand driven curricula. The scale cumulatively had 70 items covering components of the programmme, study conditions, study provisions, usefulness of studies, teaching-learning environment, study programme as basis for future professional life. For ease of interpretation, the 5-point Likert-type scale was collapsed into 3 of highest positive rating (very good and excellent); moderate rating (good) and highest negative rating (poor and fair). The actual mean score of the scale is 3 ; which implies that mean score above 3 indicates positive rating while mean score below 3 shows negative rating.

In Table 4, on the components of the program, out of 17 statement rated by alumni, adult education approaches and supervised enterprise projects (SEPs) have highest positive rating. This may be due to the adherence of the universities to the application of adult learning principles in the training of mid-career extension officers as stated in the SAFE blueprint for the delivery of the curricula. Fund raising (2.80) and scholarship (2.32) had highest negative rating and career ready education highest moderate rating. These results may be because the only competitive scholarship attached to the SAFE program was only for females due to the much fewer ratio of female extension officers to farmers. The alumni rated the curricula for making them career ready. Dromgoole, and Cummings, (2020) stated that it is important to enlist adult teaching techniques to ensure effectiveness in an extension educational programme

Table 4: Alumni's assessment of Components of SAFE programme

\begin{tabular}{lll}
\hline Components attributes & Mean & Std. Deviation \\
\hline Demand-driven curriculum (SAFE for extension only) & 3.61 & 1.009 \\
Specialized curriculum (SAFE) & 3.60 & .908 \\
Appropriateness of curriculum & 3.70 & .872 \\
Life- long learning & 3.53 & .832 \\
Adult education approaches & 3.67 & .863 \\
Supervised enterprise projects & 3.86 & .911 \\
Technology village/ Enterprise center & 3.79 & .985 \\
Rural leadership development & 3.20 & 1.006 \\
Fund raising & 3.35 & .925 \\
Scholarship & 2.80 & 1.137 \\
Involvement of stakeholders/ participatory approaches & 2.32 & 1.250 \\
Agribusiness/ Entrepreneurship drive & 3.06 & 1.099 \\
Employability / job creation & 3.21 & .994 \\
Career ready education & 3.11 & 1.033 \\
The extent curricula contributed to skill development & 3.44 & 1.018 \\
The extent curricula contributed to current job & 3.74 & .968
\end{tabular}


Creative Commons User License: CC BY-NC-ND

Abstracted by: EBSCOhost, Electronic Journals Service (EJS),

Google Scholar, Journal Seek, Scientific Commons,

Food and Agricultural Organization (FAO), CABI and Scopus
Journal of Agricultural Extension

Vol. 25 (2) April, 2021

ISSN(e): 24086851; ISSN(Print); 1119944X

http://journal.aesonnigeria.org

http://www.ajol.info/index.php/jae

Email: editorinchief@aesonnigeria.org

The study conditions were rated by alumni in terms of 10 statements used as descriptors for study conditions (Table 5). Supervision of students \& academic advice had highest positive rating; the peculiarity and the demographics of the midcareer students enrolled for the programme might have been responsible for this results. Learning conditions had highest moderate rating; which may be attributed to the design of the programme and the readiness for the university to host such programme that have been demonstrated in the introductory phases of the inception of the SAFE programme in each of universities. Opportunity for enrolling and be part of a professional scientific network, linkage with SAA field activities \& involvement in SAA field activities had highest negative rating. This may be because the expected synergy that the mid-career students expected with professional groups and field operations of Sasakawa Africa Association did not receive adequate emphasis during their studies.

Table 5: Alumni's rating of study conditions in SAFE programme

\begin{tabular}{lll}
\hline Study conditions & Mean & Std. Deviation \\
\hline Admission Process & 3.37 & 1.054 \\
Supervision of Students & 3.58 & 1.046 \\
process graduation and awards of certificates & 3.63 & .998 \\
Opportunity to have contact with teaching staff outside & 3.61 & .973 \\
Academic advice & 3.56 & .931 \\
Exposure to research projects & 3.66 & .880 \\
Learning conditions & 3.45 & .932 \\
Opportunity for enrolling and be part of a professional & 3.29 & .984 \\
scientific network & 3.11 & 1.027 \\
Linkage with SAA field activities & 3.04 & .988 \\
Involvement in SAA field activities & &
\end{tabular}

In Table 6, twenty-two statements were used by alumni to rate the study provisions across the universities. Information sharing had highest positive rating, community service and outreach had highest moderate rating while laboratories / social laboratories and variety of subjects offered had highest negative ratings. These ratings may be due to the fact that information sharing and community outreach were more prominent among the mid-career students while there was much emphasis on agricultural extension to the detriments of other subject fields 
Creative Commons User License: CC BY-NC-ND

Abstracted by: EBSCOhost, Electronic Journals Service (EJS),

Google Scholar, Journal Seek, Scientific Commons,

Food and Agricultural Organization (FAO), CABI and Scopus

http://eoi.citefactor.org/10.11226/v25i2
Journal of Agricultural Extension

Vol. 25 (2) April, 2021

ISSN(e): 24086851; ISSN(Print); 1119944X

http://journal.aesonnigeria.org

http://www.ajol.info/index.php/jae

Email: editorinchief@aesonnigeria.org

Table 6: Alumni's assessment of study provisions in SAFE programme

Study provisions Mean Std. Deviation

\begin{tabular}{lll}
\hline Library & 2.97 & 1.086 \\
Information Communication Technology & 3.28 & .935 \\
Learning modules & 3.23 & .960 \\
Learning space & 3.12 & 1.014 \\
Laboratories / Social laboratories & 3.23 & 1.032 \\
Variety of subjects offered & 3.02 & 1.237 \\
Accommodation & 2.76 & 1.159 \\
Student centre and facilities, Recreational space & 3.00 & 1.141 \\
study experiences & 3.28 & 1.003 \\
Classroom learning & 3.20 & 1.000 \\
Internship programme/ field course /practicum & 3.04 & .984 \\
Community service and outreach & 3.11 & .905 \\
Conducting research/ dissertation/ research paper & 3.06 & .957 \\
Student organization & 2.98 & .980 \\
Extra- curricular activities & 2.87 & 1.071 \\
Recreation and sports & 2.88 & 1.080 \\
Alumni Activities & 2.93 & 1.052 \\
Alumni association & 2.95 & 1.118 \\
Meetings & 2.96 & 1.080 \\
Networking & 2.91 & 1.099 \\
Information sharing & 3.22 & 1.096
\end{tabular}

In Table 7, five statements were used by alumni in the rating of the usefulness of studies, majority of the alumni stated that the studies were useful for their future professional development/career and thus highest positive rating was recorded for the statement. The usefulness of the studies for fulfilling present professional tasks, had the highest moderate rating; while the usefulness of the studies for the economic development of the country had the highest negative rating. These results may be due to the fact that career development and breaking career ceiling was a major springboard for many alumni that enrolled for the programme. 
Creative Commons User License: CC BY-NC-ND

Abstracted by: EBSCOhost, Electronic Journals Service (EJS),

Google Scholar, Journal Seek, Scientific Commons,

Food and Agricultural Organization (FAO), CABI and Scopus
Journal of Agricultural Extension

Vol. 25 (2) April, 2021

ISSN(e): 24086851; ISSN(Print); 1119944X

http://journal.aesonnigeria.org

http://www.ajol.info/index.php/jae

Email: editorinchief@aesonnigeria.org

Furthermore, Table 7, shows that alumni rated the study programme at the university being a good basis for professional development in terms of starting work as the highest positive rating, development of entrepreneurial skills as the highest moderate rating and level of satisfaction with the university services as the highest negative rating. These may be attributed to the mainstreaming of value-chain orientation into the curricula and the deviation from the conventional university norms of studies in the demand-driven curricula. Kanté, Moore, Akeredolu, Edwards, Annor-Frempong, \& Moriba (2016) stated that human resource development in agricultural extension should address the match between an organization's needs and the human resources, knowledge, and skills available.

Table 7: Alumni's rating of SAFE programme usefulness and as basis for professional development Usefulness of studies:

Mean Std.

Deviation

for finding an adequate job after finishing your studies?

for fulfilling your present professional tasks, if applicable?

$3.48 \quad 1.001$

for your future professional development/career?

$3.56 \quad 1.069$

for the development of your personality?

$3.63 \quad 1.063$

for the economic development of the country

$3.78 \quad .992$

Basis of professional development

Starting work?

$3.69 \quad .946$

Further learning on the job?

$3.42 \quad .971$

Performing your current work tasks?

$3.67 \quad 2.133$

Potential/future career(s)?

3.621 .008

Your personal development?

$3.56 \quad .995$

Development of entrepreneurial skills?

$3.68 \quad .880$

Utilization of knowledge and skills acquired during study in current job?

Level of satisfaction with the University Services

In Table 8, the teaching- learning environment sub section of the rating scale had eight statements and alumni indicated participation in research projects/ project based as the highest positive rating; practical exercises/ field work \& discussions as the highest moderate rating and seminar as the highest negative rating. This may be because the major focus of the programme is to enhance the competence of midcareer students through more of experiential learning as against the usual curriculum 
Creative Commons User License: CC BY-NC-ND

Abstracted by: EBSCOhost, Electronic Journals Service (EJS),

Google Scholar, Journal Seek, Scientific Commons,

Food and Agricultural Organization (FAO), CABI and Scopus

http://eoi.citefactor.org/10.11226/v25i2
Journal of Agricultural Extension

Vol. 25 (2) April, 2021

ISSN(e): 24086851; ISSN(Print); 1119944X

http://journal.aesonnigeria.org

http://www.ajol.info/index.php/jae

Email: editorinchief@aesonnigeria.org

with less of practice. Naibakelao, Akeredolu, and Oladele (2017) reported that SAFE graduates had more competence on dissemination of climate smart agricultural practices than convention agricultural extension degree graduates.

Table 8: Alumni's rating of Teaching - learning environment in SAFE programme

\begin{tabular}{lll}
\hline Teaching - learning environment & Mean & Std.Deviation \\
\hline Lectures & 3.44 & 1.026 \\
Demonstrations & 3.35 & 1.029 \\
Participation in research projects/ project based & 3.35 & 1.029 \\
Internship & 3.30 & 1.136 \\
Practical exercises/ Field work & 3.33 & 1.030 \\
Discussions & 3.30 & 1.034 \\
Seminar & 3.22 & 1.054 \\
Workshop & 3.18 & 1.100 \\
\hline
\end{tabular}

The results of the multiple regression analysis of the programme rating and socioeconomic characteristics of alumni are presented in Table 9 . The table shows that $R$ is 0.699 , $R$ square is $0.488, F$ is 2.33 , at $p=0.003$. This implies that the model is fit at 0.003 . There is also a multiple correlation between the programme rating and socio-economic characteristics of alumni, with about 49 percent off the variation in programme rating explained by the socio-economic characteristics. Six variables out of 17 independent variables are significant. These are age of alumni in years $(t$ $=2.564)$; marital status $(\mathrm{t}=1.924)$; university attended $(\mathrm{t}=-2.476)$; year of graduation $(t=3.123)$; title of degree $(t=3.163)$ and areas of specialization $(t=1.943)$.

The result implies that the age of alumni would influence their rating of SAFE programme as age would have impose certain exposure with experience on the midcareer students to be able to assess the effectiveness of the programme. Similarly, the marital status of the alumni is significantly related to programme rating as the level of conflict of roles would predispose the alumni to the flexibility of the programme. The variations in the management of alumni across the universities by staff of the programme could be responsible for the variances and hence the significant relationship with programme rating. In the same vein, the change in the management of SAFE programme across the universities through acquisition of competence of the methodology and compliance with SAFE methodology could be attributed to the significance of year of graduation and programme rating. The significant relationships recorded between title of degree, areas of specialization and 
Creative Commons User License: CC BY-NC-ND

Abstracted by: EBSCOhost, Electronic Journals Service (EJS),

Google Scholar, Journal Seek, Scientific Commons,

Food and Agricultural Organization (FAO), CABI and Scopus

http://eoi.citefactor.org/10.11226/v25i2
Journal of Agricultural Extension

Vol. 25 (2) April, 2021

ISSN(e): 24086851; ISSN(Print); 1119944X

http://journal.aesonnigeria.org

http://www.ajol.info/index.php/jae

Email: editorinchief@aesonnigeria.org

programme rating could be due to the level of compliance by universities to the SAFE method of training extension agents and adherence to the agricultural extension focus of the demand-driven curricula.

Table 9: Relationship between programme rating and alumni socio- economic characteristics

\begin{tabular}{|c|c|c|c|c|}
\hline & \multicolumn{2}{|c|}{$\begin{array}{l}\text { Unstandardized } \\
\text { Coefficients }\end{array}$} & \multicolumn{2}{|c|}{$\begin{array}{l}\text { Standardized } \\
\text { Coefficients }\end{array}$} \\
\hline & $\mathrm{B}$ & Std. Error & Beta & $\mathrm{t}$ \\
\hline (Constant) & -6391.781 & 2110.001 & & $-3.029^{*}$ \\
\hline Sex of graduate & 8.174 & 7.455 & .075 & 1.096 \\
\hline Age of graduate in years & 1.177 & .459 & .207 & $2.564^{*}$ \\
\hline Marital Status & 8.604 & 4.471 & .133 & 1.924 \\
\hline $\begin{array}{l}\text { Level up to which your father have } \\
\text { studied }\end{array}$ & 1.438 & 3.077 & .037 & .467 \\
\hline $\begin{array}{l}\text { Level up to which your mother have } \\
\text { studied }\end{array}$ & -4.427 & 3.080 & -.113 & -1.437 \\
\hline Fathers Occupation & 1.472 & 1.000 & .101 & 1.473 \\
\hline Mothers Occupation & -.114 & .901 & -.009 & -.127 \\
\hline Brothers Occupation & .506 & .719 & .048 & .703 \\
\hline Sisters Occupation & .721 & .763 & .067 & .945 \\
\hline From which University did you graduat & -7.495 & 3.027 & -.302 & $-2.476^{*}$ \\
\hline When was the year of graduation & 3.261 & 1.044 & .249 & $3.123^{*}$ \\
\hline Title of degree received at University & 13.260 & 4.193 & .396 & $3.163^{*}$ \\
\hline Class of degree received & 2.551 & 5.258 & .033 & .485 \\
\hline $\begin{array}{l}\text { Please state any special area trained } \\
\text { for }\end{array}$ & 2.853 & 1.468 & .142 & 1.943 \\
\hline Year awarded degree & -.001 & .010 & -.005 & -.082 \\
\hline Mode of Study & 14.049 & 42.628 & .021 & .330 \\
\hline $\begin{array}{l}\text { Do you possess any other tertiary } \\
\text { qualification }\end{array}$ & -23.055 & 25.844 & -.060 & -.892 \\
\hline $\mathrm{R}$ & 0.699 & & & \\
\hline R Square & 0.488 & & & \\
\hline Adjusted R & 0.91 & & & \\
\hline $\mathrm{F}$ & 2.33 & & & \\
\hline$P$ & 0.003 & & & \\
\hline
\end{tabular}

\section{Conclusion and Recommendations}

This study found that alumni's assessment of demand-driven agricultural extension curricula by Sasakawa Africa Fund for Extension Education in terms of the components of the programmme, study conditions, study provisions, usefulness of studies, teaching-learning environment, study program as basis for future professional life were positively rated by majority of the alumni, albeit with few areas highlighted for major improvement. Adult education approaches, supervised 
Creative Commons User License: CC BY-NC-ND

Abstracted by: EBSCOhost, Electronic Journals Service (EJS), Google Scholar, Journal Seek, Scientific Commons,

Food and Agricultural Organization (FAO), CABI and Scopus
Journal of Agricultural Extension

Vol. 25 (2) April, 2021

ISSN(e): 24086851; ISSN(Print); 1119944X

http://journal.aesonnigeria.org

http://www.ajol.info/index.php/jae

Email: editorinchief@aesonnigeria.org

enterprise projects, students' supervision, academic advice, information sharing, and participation in research projects had highest positive rating; while fund raising, scholarship, opportunity for enrolling and be part of a professional scientific network, linkage \& involvement with Sasakawa Africa Association (SAA) field activities, laboratories and variety of subjects offered had highest negative rating. These areas have implications for review of the demand-driven curricula across the universities to ensure compliance with the methodology of experiential learning to improve the competence of extension agents. It is also important that alumni have more roles to play in the unfolding synergy of the universities' and field activities of Sasakawa Africa Association. There is need to review the curricula and mechanisms for compliance with the Sasakawa methodology should be reinvigorated.

\section{References}

Alabi, O. S., Ajayi, A. O., Fapojuwo, O. E. and Alabi, T. O. (2020) Extension agents' competency needs in rural development activities in Southwest Nigeria. Nigerian Journal of Rural Sociology 20(1): 120-126 June, 2020.

Billings, D. M., and Halsted, J. A. (2016). Teaching in nursing: A guide for faculty (5th ed.). St. Louis, MO: Saunders. Commission on Collegiate Nursing Education. CCNE standards \& professional nursing guidelines. Retrieved from www.aacn.nche.edu/ccne-accreditation/ standards-proceduresresources/baccalaureate-graduate/standards

Blumenstyk, G (2019) Career-Ready Education: Beyond the skills gap, tools and tactics for an evolving economy. The Chronicle of Higher Education. 2019-CareerReady-Higher-Ed-Strada-Chronicle-of-Higher-Ed.pdf (theqacommons.org)

Cobb, K.A., Brown, G.A., Hammond, RH., Mossop, L.H. (2015) Alumni-based evaluation of a novel veterinary curriculum: are Nottingham graduates prepared for clinical practice? Veterinary Record Open 2: e000116. doi: 10.1136/vetreco-2015000116

Dromgoole, D A. and Cummings, S (2020) Effectively Teaching Adults in Extension. Effectively Teaching Adults in Extension EXCITE - Extension Career Intern Training and Education Program (agrilife.org)

Ghimire, R. P. (2017) Extension professionals preparedness for demand-driven agriculture extension services in Nepal. Journal of Extension Systems 33(01). DOI: $\underline{10.18765 / \text { jes.v33i01.10580 }}$

Kalule, S.W., Sseguya, H., Ongeng, D. and Karubanga, G. (2019) Facilitating conditions for farmer learning behaviour in the student-to-farmer university outreach. The Journal of Agricultural Education and Extension, 25:3, 211225, DOI: $\underline{10.1080 / 1389224 X .2019 .1604389}$ 
Creative Commons User License: CC BY-NC-ND

Abstracted by: EBSCOhost, Electronic Journals Service (EJS), Google Scholar, Journal Seek, Scientific Commons,

Food and Agricultural Organization (FAO), CABI and Scopus

http://eoi.citefactor.org/10.11226/v25i2
Journal of Agricultural Extension

Vol. 25 (2) April, 2021

ISSN(e): 24086851; ISSN(Print); 1119944X

http://journal.aesonnigeria.org

http://www.ajol.info/index.php/jae

Email: editorinchief@aesonnigeria.org

Kanté, A., Moore, A, Akeredolu, M, Edwards, M. C., Annor-Frempong, F, \& Moriba S (2016) Human Resource Development for Agricultural Extension and Advisory Services Training, Adult Learning, and Field Methods. Discussion paper by U.S. Agency for International Development (USAID) project Modernizing Extension and Advisory Services (MEAS) www.meas-extension.org.

Kumm, S., Laverentz, D. M. (2017) Concept-Based Curriculum Evaluation: 5-Year Process,

Teaching and Learning in Nursing, Volume 12, Issue 4, Pages 242-245. https://doi.org/10.1016/j.teln.2017.06.004.

López-Entrambasaguas, O. M., Calero-García, M. J., Díaz-Meco-Niño, A. M., and MartínezLinares, J. M. (2019). Quality assurance in nursing education: A qualitative study involving students and newly graduated nurses. International journal of environmental research and public health, 17(1), 240. https://doi.org/10.3390/ijerph17010240

Naibakelao, D.; Akeredolu, M.; Oladele, O.I.(2017) Capacity development for scaling up Climate Smart Agriculture: The Sasakawa Africa Fund for Extension Model of experiential learning. Paper presented at The 3rd AFAAS Africa-Wide Agricultural Extension Week combined with the 51st Annual Conference of the South African Society for Agricultural Extension. Event Theme: "Scaling up climate smart agriculture: integrating youth, women, and the digital revolution". 30 October - 3 November 2017. Durban, KwaZulu Natal, South Africa.

National Universities Commission (NUC) (2018) Curriculum Development and Planning. Academic Planning | National Universities Commission (nuc.edu.ng). Accessed November, 2020.

Oladele O I (2020) Sasakawa africa fund for extension education: A review of demanddriven agricultural extension education in Nigeria. Accepted for publication in Journal of Agricultural Extension.

Olorunfemi, T.O. Olorunfemi, O.D. Oladele, O.I. (2020) Determinants of the involvement of extension agents in disseminating climate smart agricultural initiatives: Implication for scaling up. Journal of the Saudi Society of Agricultural Sciences, Volume 19, Issue 4: 285-292,

Sasakawa Africa Association (SAA) (2020). Sasakawa Africa Association Strategic plan 2017-2023

Sasakawa Africa Association (SAA) (2018). Sasakawa Africa Association Annual Report

Smith, D. (2020) A Complete Guide to the Kirkpatrick Model of Training Evaluation. A Complete Guide to the Kirkpatrick Model of Training Evaluation (bizlibrary.com)

Suvin, M. C. (2018) Outcome Based Education - what is it all about? Outcome Based Education OBE - what is it all about? Accessed November 2020 
Creative Commons User License: CC BY-NC-ND

Abstracted by: EBSCOhost, Electronic Journals Service (EJS),

Google Scholar, Journal Seek, Scientific Commons,

Food and Agricultural Organization (FAO), CABI and Scopus

http://eoi.citefactor.org/10.11226/v25i2
Journal of Agricultural Extension

Vol. 25 (2) April, 2021

ISSN(e): 24086851; ISSN(Print); 1119944X

http://journal.aesonnigeria.org

http://www.ajol.info/index.php/jae

Email: editorinchief@aesonnigeria.org

Valiga, T. (2017). Curriculum evaluation. InM. Oermann (Ed.), A systematic approach to assessment and evaluation of nursing programs (pp. 19-28).

World Bank, (2015). For Up to 800 Million Rural Poor, a Strong World Bank Commitment to Agriculture

Available

at http://www.worldbank.org/en/news/feature/2014/11/12/for-up-to-800-million-ruralpoor-a-strong-world-bank-commitment-to-agriculture 